\title{
Transatlantica
}

Revue d'études américaines. American Studies Journal

\section{Masculinities and Markets: An Interview with Brenda Parker}

\section{George Katito}

\section{(2) OpenEdition}

Journals

Electronic version

URL: https://journals.openedition.org/transatlantica/16439

DOI: 10.4000/transatlantica.16439

ISSN: 1765-2766

\section{Publisher}

Association française d'Etudes Américaines (AFEA)

Electronic reference

George Katito, "Masculinities and Markets: An Interview with Brenda Parker", Transatlantica [Online], 2 I 2020, Online since 01 March 2021, connection on 01 February 2023. URL: http://

journals.openedition.org/transatlantica/16439; DOI: https://doi.org/10.4000/transatlantica.16439

This text was automatically generated on 1 February 2023.

\section{(c) (i) $\odot$}

Creative Commons - Attribution-NonCommercial-NoDerivatives 4.0 International - CC BY-NC-ND 4.0

https://creativecommons.org/licenses/by-nc-nd/4.0/ 


\title{
Masculinities and Markets: An Interview with Brenda Parker
}

\author{
George Katito
}

George Katito: How did you come to work on Milwaukee as the center of Masculinities and Markets?

Brenda Parker: I see Milwaukee as a city that is both ordinary and extraordinary. By "ordinary," I mean that Milwaukee is a somewhat typical mid-sized city in the American Midwest. Its economy has shifted in the past 40 years from primarily manufacturing to services; it has a diverse ethnic and racial population; and the city has a rich history of activism with regard to topics such as women's rights, fair housing, and workers' rights. Ordinary cities like Milwaukee tend to be underrepresented or overshadowed by larger cities like New York or Chicago in urban research.

Milwaukee is also an "extraordinary" city that has experimented with relatively radical urban politics. It is one of the few US cities to have had a city government led by Socialists for many years, who touted themselves as "Sewer Socialists" beginning in the early 1900s. Yet, less than 100 years later, Milwaukee privatized those same sewers, as well as hospitals, museums, school systems, and much more. It aggressively pursued neoliberal policies, reducing city government, lowering taxes, and implementing welfare reform. By "extraordinary," I also mean that Milwaukee is among the top three most racially segregated cities in the United States and has one of the highest child poverty rates in the country. It has a unique blend of progressive and regressive politics. For example, it was one of the first cities to form a local chapter of the National Organization for Women, but is also home to influential conservative think tanks such as the Bradley Foundation.

In these ways, Milwaukee offers us a city that is both unique and relatable-a place where it is possible to explore the core and the outer edges of raced, gendered neoliberal urban politics and to reflect deeply about urban governance, inequality, crisis, and resistance. My hope is that my case study of Milwaukee, spanning the 
1900 s to early 2000 s with an emphasis on the past four decades, can resonate beyond its space and time.

GK: When you were in Paris you delivered a talk linked to your work, and you mentioned that gender and race remained "under-visible" in the study of the neoliberal city. In France, where identity politics are viewed with great suspicion, opposition to both of these themes can be quite explicit. How does one explain this "under-visibility" in the US?

BP: When I first launched the research for this book, I was motivated in part by a frustration with the increasingly popular literature on neoliberalism and cities. This literature largely focused on how cities and urban politics were products of and battlegrounds for capitalism and class. I found this literature compelling, but silent on many topics and insufficient to explain the inequalities I noticed on the ground in cities. There was a much smaller body of literature on gender, colonialism, and/or race in US cities. This seemed strange of course, as US cities were built on a foundation of colonial violence that stripped Native Americans of their land, resources, and lives. And as Du Bois noted as early as 1935, slavery and the exploitation of black labor is a "foundation stone [...] of Northern manufacture and commerce, [...] [and] new cities were built on the results of black labor" (5). In addition, women's unpaid labors as enslaved people, and in homes and communities have always buttressed the accumulation of capital and expansion of cities, while they suffered violence, oppression, and exclusion from many public spaces and spheres.

In spite of this, anti-racist feminist studies of cities were not in vogue in the early 2000s, and many urbanists simply ignored extant feminist contributions and modes of analysis. One scholar likened conducting feminist urban research to the "loneliness of the long-distance runner" (Whitzman). This can be attributed to many things, including a lingering and persistent cultural backlash against feminist, civil rights, and LGBTQ energies of the 1970s and 1980s; a related sense that we had already "done" gender and race; and the insidious cultural and discursive work of neoliberalism itself, which both debases collective activism and implies all are equal under the market. And to be frank, it is simply easier for those in power to fail to see, actively ignore, or benefit from these inequalities than to grapple with them. Of course, patriarchy, privilege, and other power relations linger in academia as well, which means many urban political scholars were not trained or particularly interested in feminist or intersectional approaches to studying cities and urban governance. Finally, for scholars and writers, there is a fundamental challenge of studying how racism, sexism, heteronormativity, capitalism, and other forms of power operate in cities in a way that accounts for so much difference and complexity. This is something I have certainly not perfected myself.

Of course, in very recent years in the United States, we have seen a re-ascendance of attention to sexism, transphobia, and racist violence via movements like "Me Too" and "Black Lives Matter." I personally have become a sharper observer of more mundane and active forms of resistance, and the growth of feminist and queer collectives, and social movements all around me. Now in the United States, there is still violence, but perhaps much less silence. Academic literatures on these topics have gained more visibility and widely proliferated, and even mainstream newspapers feature articles about transgender rights, intersectional feminism, and racist brutality. 
And as much as I feel hopeful about these movements and the growing attention to them, each also seems to have a built-in backlash already in motion. As I wrote about in Masculinities and Markets, in the early 1900s, when many female reformers like Ida B. Wells and Jane Addams assumed greater leadership in cities, constructing volunteer organizations and social fabrics that helped immigrants and families survive-they were soon pushed aside by a backlash. Women asserted a direct challenge to cold, capitalist, and racist cities by creating and leading new institutions, but men quickly took back the helm. Similarly, during World War II, women, LGBTQ+ individuals, and workers of color achieved a degree of autonomy and progress, yet this period was succeeded by backlash that (re)imposed a narrow vision of white "moral," masculine, and marketized cities and suburbs at the end of the war. In fact, while neoliberalism is mainly interpreted as an economic response to the crisis of slowed accumulation, it was also a backlash to feminist, civil rights, LGBTQ+, and other social movements of the 1970s that had profoundly ruffled the feathers of white masculine power in Milwaukee and around the United States.

GK: When we speak of masculinities and masculinist power how are these defined? Here, gay men, men of color, trans men and women, and lesbian women who assume masculine identification come to mind.

BP: This is a good question because the term "masculinities" has been problematized and made more complex in the past several years. As you point out in your question, there are many types of masculinities and people might choose to express or assume masculine identification. More than that, some forms of masculinities are more closely linked to power, authority, and privilege, where others are more subordinated. Masculine power is never mapped perfectly onto a particular body or set of bodies. I like to use Ananya Roy's (2002) concept of masculine power in cities as a "regulatory fiction,"-a kind of narrowly delineated, idealized, and disciplining subjectivity. In my research on neoliberal cities, I found that the "idealized" citizen (and city) is competitive and capitalist, focused on growth and profit, and not weighed down by burdens of care or community. These subjectivities (regulatory fictions) enabled, for example, wealthy male urban developers in Milwaukee who received million-dollar subsidies from the government to be celebrated as independent risk-takers working for the good of Milwaukee, while poor black mothers receiving modest welfare payments of $\$ 400$ a month were demeaned as dependent, needy, and selfish.

This conception of masculine power also alludes to structural power of patriarchy that has amassed over centuries and the fact that, while many people may choose to identify as masculine, they may not as easily be able to occupy these subjectivities of masculine power. There is a "material" or demographic reality here. Cities in the United States proliferated and profited because of colonialism and slavery. They have flourished in part because of women's unpaid and undervalued labor. Historically, white, cis, elite, heterosexual men have historically held the most, though not exclusive, power in cities-as architects, government officials, business leaders, urban developers, and more. And to a large extent, that power was reinforced through the (re)-ascendancy of neoliberal capitalism, which involved transfers of wealth from cities and residents to corporations and elites via privatization, increased influence over government decisions by business interests, and the reductions of social assistance and welfare-the latter which disproportionately 
benefit women, black, indigenous and people of color, and more. The neoliberal expansion of markets into new spaces, deepening of financial markets, and decreasing regulation meant more opportunities for accumulation for those who wield the most power in capitalist markets and started out with the most resources. To explain this to my students, I tell them to imagine their opponent starts out in a monopoly game with $\$ 2,000$ and they start out with nothing. Elite white men, whose dominance in local and global capitalism is relatively secure, most easily occupy idealized neoliberal subjectivities-the roving, middle-class, "creative" entrepreneur promulgated by urban commentator Richard Florida that cities like Milwaukee scrambled to attract. This obviously doesn't mean that all persons who identify as female or feminine have fared poorly in the same way under neoliberalism in cities. Not all markets or modes of exchange are equally nefarious, and not all members of a demographic group are situated in the same way, as I discuss below.

In the book, I also write about values that have been traditionally associated with masculinity and masculine power, of competition and individualism, for example, that have come to dominate in urban governance and management. And how these values have superseded values and norms associated with femininity, such as care and cooperation. As we know, people of all genders, races, ethnicities, and more can practice care and cooperation, but in part because of their association with the "feminine" and with "female" bodies, these values in Western cities are often devalued and deprioritized in analyses and practices of urban governance. This latter point is something I am exploring more in my recent research.

BP: Your question also makes me curious about how you think about different types of masculinities, power, and urban governance. How does this show up in your work and how might your perspectives contrast with or complement what I have discussed?

GK: I situate my doctoral research from the emergence of a post-Second World War global political economy up until the mid-1980s, just as the economic aftershocks at the turn of the decade were subsiding. The work wrestles with the cultural implications of the growth of American political and economic power over this period. More pointedly, it studies the American discourses, urban spatial practices, and cultural normativities of male same-sex sexuality in Paris and London that accompanied the growth of American global power. Perhaps what my work shows is how the forces that you witness at work in Milwaukee begin to take residence in cities on the other side of the Atlantic. The modes of urban governance and identity politics birthed in American cities find their way into policy discussions and political discourse on urban governance in France and the UK.

This process of displacement and the spread of American-style identity politics is experienced as emancipatory by those who welcome the power that Americanization provides to sexual and gender minorities to fight for expanded rights. Yet, this comes at the cost of erasing memory and various vocabularies for speaking about gender and sexuality that preceded the advent of an American-dominated global political, economic and cultural order.

The American-led global political economy thus appears to simultaneously liberate gay white men in cities like Paris, but also acts to subsume other "subordinated masculinities" as you refer to them-and I would add subordinated sexualities (the L, B, T, Q, I and As)invisible.

GK: I wonder then, if you could speak to the notion of the neoliberal city and its participation in perpetuating gender and racial hierarchies? Is this a strictly antagonistic relationship? Do 
markets also play a role in liberating oppressed groups through the wider distribution of financial independence and power?

BP: This is an interesting question with a straightforward and then a less straightforward reply. The primary answer is that the notion of capitalism (and its amplification vis-à-vis neoliberal policies) as a liberatory and equalizing force is a tantalizing trope promulgated by neoliberalists that often disguises the fundamental transfer of wealth from the poor to the rich and the intensification of inequality that have occurred in many cities. That is often what I have seen in my research. People who are already poor and who have their social benefits reduced or labor protections taken away under neoliberal policies have become poorer. People who are oppressed and marginalized by racism, heteronormativity, sexism, and more are made more vulnerable by neoliberal capitalism, which prioritizes profit over people, demands more flexibility and subordination of workers, devalues caring endeavors, and strips social supports.

Poor women in Milwaukee, many who were Black, experienced declining welfare payments, mandates to work, and cuts to healthcare and other supports like a visiting nurses program for new mothers. While several audits and evaluations showed that welfare reform rarely lifted women out of poverty and that most women could secure only temporary low-wage jobs, it did help giant corporations who were legally able to pay welfare participants below minimum wage, accumulating wealth on the backs of these women. Overall, the wealthiest urbanists (developers, large corporations, real estate moguls), who I have already described as largely white, elite, cis, and male, profited. In 2011, while most Black female workers in Milwaukee earned less than twenty-five thousand dollars per year, the CEOs of Milwaukee's four largest companies (all male) received over thirty million in compensation.

As other scholars have noted, under neoliberalism, women overall have experienced an intensification of paid and unpaid labor. White elite women were most easily able to navigate this, often hiring poorer women of color to help them in the absence of a decent child care infrastructure in the United States. In Milwaukee and nationally, the gendered wage gap narrowed to some degree during neoliberalism. However, it persists and men retain the most valued positions in terms of prestige, pay, and power. At the time of the book's publication, full-time female workers earned 77 cents for every dollar earned by full-time male workers, and the gap between Black and Latina female workers and White male workers is far greater, closer to 60 cents on the dollar. Furthermore, many urban womyn do not work full-time, but comprise the precarious part-time or contingent workforce. This is due to historical patterns, gender discrimination, and caregiving duties that still largely fall on women's shoulders. Note I will occasionally use womyn to be inclusive of transwomen. While my Milwaukee research did not necessarily focus on transwomen, the literature is clear about the marginalization they face in labor markets and elsewhere.

Many womyn and people of color remain segmented in low-wage "feminized" jobs, including the service economy which boomed under neoliberalism. In fact, new workers filling low-paid service jobs in the 1990s were almost all unmarried mothers with a high school degree or less. Overall, the vast majority of workers in the United States labored for more hours and for lower real wages than they did 30 years ago. Finally, even the decline of less obvious endeavors, such as government programs 
that focused on hiring women or people of color, or the formation of women's councils, meant that opportunities for upward mobility (economically or in urban leadership), were often curtailed in neoliberal cities.

New working opportunities unfolded during the 1990s and 2000s. Women-owned businesses grew dramatically in Milwaukee, and some women procured flexible and less hierarchical working arrangements. However, racist, sexist, and other harmful behaviors flourished in supposedly non-hierarchical spaces. Sexual harassment, racism, unequal wages, fewer advancement opportunities, a "chilly" or aggressive office culture, and higher caregiving burdens for many women stunted their progress. As I explore in the book, the rise of "creative" and more flexible and informal careers celebrated by urban commentators like Richard Florida often meant "informal" exclusion and mistreatment for womyn in Milwaukee. And as recently documented by the "Me Too" movement, many womyn who have advanced or survived in their careers over the past decades have done so by suffering harassment in silence and pandering to elite men in charge.

Therefore, a less straightforward answer to your question has to acknowledge some of these complexities. As you suggest, markets and the capacity for individual or collective accumulation-especially if paired with the ability to determine how surplus gets allocated-can lead to autonomy, greater well-being, security, safety, and space for cultural expression. Not all labor arrangements and markets are nefarious and predatory. There is some possibility, hope, and resistance in the majority of political, economic, and social configurations. But wealth-even if neoliberalism helped generate it or if it was distributed evenly-is not a guarantee of safety or political representation-as police arrests of black people of higher stature, the abuse of wealthy women by their partners, and the fact that women still only comprise 20 percent of elected urban officials all can attest. Overall, I believe that the expansion of neoliberal capitalism in cities-combined with racism, sexism, and more -was more harmful than helpful, especially for the most marginalized populations.

My research findings also showed that inequality is not specific to or contained within capitalism or even neoliberal capitalism. Patriarchy, racism, heteronormativity, etc. are not products of capitalism, even as they are embedded in and close companions with it-stifling life opportunities and life itself via violence, control, unequal health treatment, unfair housing policy, incarceration, and more. The years prior to neoliberalism-often called the Keynesian years and perhaps romanticized by some critical urban scholars-were not especially generous to women, LGBTQ+ individuals, and people of color.

Finally, I think that neoliberalism and urban life more generally is messy and complex in how it unfolds for various people. Cities-neoliberal or not-have been places where LGBTQ+ individuals, womyn, and others have sometimes been able to find refuge and where protest, activism, and collective social life often flourish. They are places where there is often substantive difference within groups with supposedly shared identities. You have written about this in your own work, for example, about the marginalization of trans, Hispanic, and low-income gay population in New York City in the 1960s, especially prior to Stonewall. Their experiences contrasted with the more wealthy, urbane, modern, intellectual, primarily white gay men reflected in the senior membership of the Mattachine Society. And you point out how New York City 
and Stonewall were an American event that ultimately shaped a (largely white, gay male) resistance in Paris and London, even as British politics had already begun challenging sexual and gender normativities over a decade earlier. This was partly thanks to New York's position as the center of the global political economy dominated by the United States.

So cities-neoliberal or not-have been and continue to be places of persistent inequality as well as spaces for change and liberation, and much can depend on who and where you are. As you point out, cities like New York are "outsized" in their influence because of their position of power in the global political economy. To my mind, we have much more work to do to better understand how various structures of power work in concert with each other and affect particular groups at specific places and times. We also need to better understand and embrace inclusive progressive pathways and policies that do undermine or come at the expense of certain communities of people. I am not excited, for example, by the prospect of a gendered wage gap that is narrowing because men are becoming poorer.

GK: Are some of the dynamics that you discuss in your work manifestations of capitalistic / economic crisis? Or related to broader economic crises-be it local, national, or even global?

BP: Certainly. The ascension of neoliberalism is clearly linked to the economic recession of the 1970s and related urban population and revenue decline, as well as a crisis for white male power that feminist, civil rights, and other movements had helped create. As Koutrolikou reminds us "crisis becomes simultaneously a situation to be governed and a strategy through which governance arrangement and other measures are introduced or enforced" (174). Neoliberalism was an attempt at a political economic and social fix, accompanied by targeted discourses and narrations that blamed particular people, practices, and policies for economic stress. In New York City, Milwaukee, Chicago, and elsewhere, workers, people of color, women, and activists more generally were faulted for crisis and inequality, while little was made of greedy actions of investors. Media stories about black "welfare queens" abusing government resources proliferated. Purportedly bloated and inept government and overly generous welfare programs were blamed for the stagnation of economic growth, seeming to justify cuts in taxes, services, and social benefits. These policies and discourses served the dual purpose of reinforcing certain forms of racial and gender inequality and reinvigorating markets, ushering in an era of remarkable disparity in the United States. Right-wing political strategists of the 1970s have admitted to intentionally using abstract "economic" strategies, such as lowering taxes and services, that would be more harmful to black Americans than white Americans. These discursive and material strategies had harmful effects and swayed hearts and minds-by the 1980s support for women's rights and civil rights in the United States had considerably fallen.

I am not alone in arguing that capitalism, by nature, is prone to crisis. History has shown us that those in power will try to use economic, social, and political crises to their advantage. They will attempt to narrate crisis in ways that disguise the fundamental inequalities and inevitabilities baked into the capitalist, racist, heteronormative, patriarchal, and otherwise power-laden structures in which we live. However, there is space for hope. What I have learned is that crises-however they originate-also create opportunity for those who hold less power. They often 
expose what is broken or harmful or insidious. Like my teenagers at home, they deftly reveal hypocrisy. A crisis can bring people together and allow alternatives forms of social organization to emerge, to become more visible, or to become politically viable at a larger scale. In Milwaukee and elsewhere, I have observed antiracist, queer, feminist, and otherwise diverse alliances grounded in values of commoning and care. These kinds of alliances are complex and imperfect, as your own research demonstrating the tenuous alliances between the nascent gay liberation movement and radical black politics of the 1960s demonstrates. However, before and during crisis, I have watched these collectives challenge a city that chose profit over people, and work against the brutalities of capitalism, patriarchy, racism, and the carceral state. My current research focuses on these historic and evolving practices of collectivity and resistance. In 2020-a year of pent-up and profound crises in the United States and elsewhere-we have much to learn from these endeavors. We have an opportunity to (re)build our cities based on collectivity and care, and to reject the violences and silences that were so prevalent in my research on raced and gendered neoliberalism in Milwaukee.

BP: In your current postdoctoral research you are exploring the relationships between political economic crises and gender and racial identity politics. And you are in Paris while I am in Chicago. Based on your location and current and previous research, what concerning dynamics and / or hopeful possibilities for transformation do you see in 2020 ?

GK: It's remarkable to witness reconfigurations to the international political economy in real time that I saw while working through Paris's LGBTQ+ archives of the 1980s.

The current global public health and economic crises are changing the composition and direction of global trade-as certain industries rapidly expand and others face annihilation. Similarly, various forms of labor have become more mobile as technology and the exigencies of virtual work destabilize fixed ideas of how and where work is done. We are also being forced to revisit notions of value and how labor is priced and valorized. All these factors have a bearing on how gender and sexuality are defined, spatialized and expressed. This is a familiar scene that echoes post-World War Two labor and global trade shifts that opened up traditionally male-dominated workplaces to women and gave queer folk the economic means to more securely express nonconformist sexualities. This ought to give us hope that the current changes that we are seeing on a macroeconomic level, at least in the West, will translate into changes in how gender and sexuality are organized.

The current economic context is also accompanied by new spatial practices as virtual work forces a contraction of the barriers between home and work. This has complex implications for our understandings of sexuality, sex, and gender. In Chicago, perhaps the wall between home and work was already quite thin anyway, but in Paris, the division between the private and public is deeply etched into policy and practice. A thinning of the frontier between office and home here could be liberating, yes, or it could actually consolidate traditional inequalities in the division of labor even as home life dwarves work responsibilities, particularly for women.

In this context of shrinking borders between the public and private, intimate struggles tied to race have also become more visible as American movements for racial equality energize fatigued, barely visible Parisian ones. Interestingly, however, Black Lives Matter has inspired backlash. In my analysis of Twitter and Instagram statistics on Black Lives Matter in Paris, the greatest volume of engagement with Black Lives Matter content has been generated by energized and surprisingly popular right-wing figures.

The potential promise and pitfalls that come with the current, turbulent global economic context will hopefully yield more of the liberating spatial, economic, and cultural practices 
that come with changed labor and trade realities-and less of the anxiety and backlash that

is currently simmering online and could easily spill over into the real world.

\section{BIBLIOGRAPHY}

DU BOIS, W.E.B. Black Reconstruction in America, 1860-1880. 1935. New York: The Free Press, 1998.

FLORIDA, Richard. The Rise of the Creative Class and How It's Transforming Work, Leisure, Community and Everyday Life. New York: Basic Books, 2002.

KATITO, George. "Pink Atlantic: American Global Power and the Construction of Gay Identities in Paris and London (1940s-1980s).” PhD dissertation, Sorbonne Université, 2020.

KOUTROLIKOU, Penny. “Governmentalities of Urban Crises in Inner-city Athens, Greece.” Antipode, vol. 48, no. 1, 2016, p. 172-192.

PARKER, Brenda. Masculinities and Markets: Raced and Gendered Urban Politics in Milwaukee. Athens: University of Georgia Press, 2017.

ROY, Ananya. City Requiem, Calcutta: Gender and the Politics of Poverty. Minneapolis: University of Minnesota Press, 2002.

WHITZMAN, Carolyn. "The Loneliness of the Long-Distance Runner: Long-Term Feminist Planning Initiatives in London, Melbourne, Montréal and Toronto." Planning Theory \& Practice, vol. 8 no. 2, 2007, p. 205-227.

\section{ABSTRACTS}

Brenda Parker's book Masculinities and Markets centers this conversation. From discussing how Milwaukee stands out as an American case study of raced, gendered, neoliberal urban politics to a transatlantic reading of the neoliberal city, this author interview explores the paradoxes and entanglements of masculinities and power with urban governance. Parker extends her reflection of these tensions as she brings her work into dialogue with the interviewer George Katito's recent work on how global political economic forces impinge upon how masculinities simultaneously collide with and shape process of urban governance.

Cet entretien porte principalement sur l'ouvrage de Brenda Parker Masculinities and Markets. La conversation se concentre initialement sur le cas de Milwaukee (dont l'étude fonde l'ouvrage de Parker), ville marquée par les politiques urbaines néolibérales et de fortes hiérarchies de race et de genre, puis évolue vers une lecture transatlantique de la ville néolibérale et explore la manière dont les enjeux politiques de la masculinité s'articulent avec la gouvernance urbaine. L'entretien prolonge la réflexion de Parker sur ces questions en prenant en compte les récentes recherches de son interlocuteur, George Katito, sur la manière dont les masculinités, influencées par les forces économiques mondiales, interfèrent avec le processus de gouvernance urbaine et peuvent en même temps le façonner. 
INDEX

Keywords: masculinities, gender, urban governance, race, neoliberalism, queer cities

Mots-clés: masculinités, genre, gouvernance urbaine, race, néolibéralisme, villes queers

\section{AUTHOR}

\section{GEORGE KATITO}

Sorbonne Université 